Makale Geliş | Received: 15.08.2018

Makale Kabul | Accepted: 26.08.2018

DOI: 10.18795 /gumusmaviatlas.453800

Mavi Atlas, 6(2)/2018: 118-137. Araştırma Makalesi | Research Article

\begin{abstract}
Nafiz MADEN
Dr. Öğr. Üyesi | Assist. Prof. Dr Gümüşhane Üniversitesi, Mühendislik ve Doğa Bilimleri Fakültesi, Jeofizik Mühendisliği Bölümü, Gümüşhane, TR Gümüşhane University, Fac. of Engineering and Natural Sciences, Dep. of Geophysical Engineering, Gümüşhane,TR

ORCID: 0000-0001-5201-850X

nmaden@gumushane.edu.tr
\end{abstract}

Yasemin BEKER

Arș. Gör. | Res. Assist.

Gümüşhane Üniversitesi, Mühendislik ve Doğa Bilimleri Fakültesi, Jeofizik Mühendisliği Bölümü, Gümüşhane, TR Gümüşhane University, Fac. of Engineering and Natural Sciences, Dep. of Geophysical Engineering, Gümüşhane,TR

ORCID: 0000-0001-5045-7808

bekeryasemin@gumushane.edu.tr

Bayram NAZIR

Prof. Dr.

Gümüşhane Üniversitesi, Edebiyat Fakültesi, Tarih Bölümü, Gümüşhane, TR Gümüşhane University, Faculty of Arts, Department of History, Gümüşhane, TR ORCID: 0000-0002-4098-1304

bayramnazir@gmail.com

\title{
Theophanes Kroniğinde Doğa Olayları ve Yer Bilimleri Gözlemleri
}

\section{Öz}

Bu çalışmanın amacını Bizanslı tarihçi Theophanes'in MS 284-813 yılları arasındaki olayları anlattı̆̆ kroniğindeki doğa olayları ve yer bilimleri gözlemleri oluşturmaktadır. Theophanes 758/760 yıllarında İstanbul'da zengin ve aristokrat bir ailenin çocuğu olarak doğmuş ve 818 yılında sürgünde olduğu Semadirek adasında vefat etmiştir. Annesi Theodora, babası ise Bizans İmparatorluğu'nun Akdeniz'deki adalarının valisi Isaakios'dur. Theophanes, 810/811 yıllarında ölen Georgios Synkellos'un teşvik ve arzusuyla onun yarım kalan kroniğini devam ettirmeye karar vermiştir. MS 284-813 yıllarında arasını kapsayan "Chronographia” isimli eserini 810-814 yıllarında tamamlamıştır. 90 adet doğa olayı ve yer bilimleri kaydına yer veren Theophanes'in kroniği çok eski kaynaklara ulaşması ve kaybolmuş kaynakları kullanması açısından oldukça önemlidir.

Anahtar Kelimeler: Theophanes, Bizans, Doğa gözlemleri, Yer Bilimleri Kayıtları

\section{Natural Events and Earth Sciences Observations in the Chronicle of Theophanes}

\section{Abstract:}

The purpose of this work is the natural phenomena and earth sciences observations recorded in the chronicle of the Byzantine historian Theophanes from AD 284 to 813. Theophanes was born in 758/760 in Istanbul as a child of a wealthy and aristocratic family and died in exile of Samothroke island in 818. His mother name is Theodora and his father is Isaakios, the governor of the Mediterranean islands of the Byzantine Empire. Theophanes decided to continue unfinished chronic of Georgios Synkellos who died in the year 810/811 with the encouragement and desire of him. He completed his work entitled "Chronographia" covering the period between 284 and 813 years in 810-814. The chronicle of 
Theophanes including 90 natural events and earth sciences records is very important in terms of using very old and lost resources.

Keywords: Theophanes, byzantine, Natural observations, Earth Sciences records

\section{Giriş}

Theophanes, asil ve zengin bir ailenin çocuğu olarak İstanbul'da doğmuştur (758/760-12 Mart 817/818). Babası Akdeniz adaları imparatorluk valisi İsaakious, annesi ise Theodora'dır. Üç yaşında babasının ölmesi ve yetim kalması üzerine Bizans imparatoru Theophanes'i sarayda himaye etmiş ve eğitimi ile ilgilenmiştir. Theophanes 20 yaşında evlenmiştir. 799 yılında imparatorun ölümünden sonra Theophanes Marmara Denizi'nin Anadolu tarafında Sigriane ${ }^{1}$ isimli bölgede kurduğu manastırda 815/816 y1lına kadar dini bir hayat sürmüştür (Turtledove 1982: Viii; Mango vd. 1997: Xiii).

İkonoklazm, Bizansta V. Leo (813-820) tarafından yeniden canlandırıldı. Theophanes, çoğu keşiş gibi, kutsal sembollerin imha edilmesini reddetti ve ikinci İznik Konsili'nde ikonaların kutsandığı kararlara imza attı. Bizans imparatoru V. Leo (813820)'a muhalefeti için tutuklanarak İstanbul'da hapsedildi ve 818 yılında öldüğü Samothrake $^{2}$ adasına sürüldü. Ölümünden sonra birçok mucizeleri olduğuna inanılarak Doğu Kilisesi tarafindan Aziz ilan edildi (Turtledove 1982: IX; Mango vd. 1997: XIX).

Theophanes'in Kroniği aslında 810 ya da 811 yılında ölen çok yakın dostu papaz George Synkellos'un Âdem'den MS 284 y1lına kadar olan olayları anlattı̆̆ “Chronographia” adlı eserinin devamıdır. Dolayısıyla Theophanes'in Kroniği yaradılıştan başlamaz. Theophanes MS 284-813 yılları arasındaki olayları anlattığı kroniğini George Synkellos'un ölümünden sonra MS 814 yılında tamamlamıştır. Şu an kaybolmuş çok eski kaynaklara ulaşarak kronolojik olarak dünya tarihine ait olayları yazdığ 1 Theophanes'in eseri V. Leo'nun (813-820) imparator olduğu yılda son bulmuştur. Eser özellikle VII-VIII. yüzyıllardaki olayların aydınlatılması açısından oldukça önemlidir (Turtledove 1982: 176; Mango vd. 1997: 681).

Theophanes'in Kroniği üzerinde birçok araştırmacı (Bakır 2005: 3-9; Karatay 2010: 1-18; Bahadır 2011: 685-703; Berbercan 2013: 219-230; Karatay 2014: 51-57; Koçak 2015: 67-76) çalışmalar yapmış ve döneminin olaylarına açıklık kazandırmaya çalışmıştır. Bakır (2005: 3, 8), İstanbul şehri ve çevresinde IV-XV. yüzyıllar arasında oluşan depremleri insanların nasıl algıladığı konusu üzerinde çalışmasını oluşturmuştur. Karatay (2010: 3, 9), Tuna Bulgar devleti üzerine yaptığı çalışmada Theophanes'in

\footnotetext{
${ }^{1}$ Bugün Kurşunlu yakınlarında Erdek ile Orhaneli Çayı arasındaki bölge.

${ }^{2}$ Yunanistan'a bağlı Semadirek adası
} 
eserini de kullanmıştır. Bahadır (2011: 685, 701), yaptığı çalışmasında Bizans-Sasani etkileşimi üzerine durmuş ve Theophanes’in Bizans ve Sasani toplumlarının IV-VII. yüzyıllar arasında evrensel denge ve düzeni sağlayarak birbirlerini tamamladıklarını savunmuştur. Berbercan (2013: 221) ve Koçak (2015: 68) Hazarlar üzerine yaptıkları çalışma sonucunda Theophanes'in Hazarları "Doğu Türkleri” olarak zikrettiğini ortaya koymuşlardır. Karatay (2014: 52) ise Karadeniz’in kuzeyinde Büyük Bulgar devleti üzerine yaptığı çalışmasında Theophanes'in Kroniğinden önemli ölçüde yararlanmıştır.

$\mathrm{Bu}$ çalışmada Theophanes'in MS 814 yılında tamamladığı kroniğinde Bizans ve çevresinde yaşanmış toplam 90 adet deprem, kuraklık-kıtlık, meteorolojik olay, güneş tutulması ve gökyüzü gözlemleri konu edinilmiştir. Yaşanan bu olayların Bizans dünyasında algılanışı ve o dönemin bilgi seviyesi hakkında değerlendirmeler bu çalışmada ortaya konulmaya çalışılacaktır.

\section{Theophanes Kroniğinde Doğa Olayları ve Yer Bilimleri Kayıtları}

Theophanes Kroniğinde doğal olaylar ve yer bilimleri kayıtları dikkate alındığında Çizelge 1'de verilen kronolojik liste oluşturulabilir. Toplam 90 adet kaydın yer aldığı liste incelendiğinde, kayıtların daha çok İstanbul ve Suriye/Filistin bölgelerine ait olduğu görülmektedir. Bu olaylara ait istatistiki bilgi ise Çizelge 2'de verilmiştir. Çizelge 2'de en fazla deprem kaydına (49 adet) yer verildiği görülmektedir. İkinci olarak Kuraklık/Kıtlık bilgisi (10 adet) kronikte yer almaktadır. Daha sonra Güneş tutulması ( 8 adet) Kuyruklu yıldız (6 adet), ve diğer gözlemlere yer verilmiştir. Bu gözlemler aşağıda ayrıntılı şekilde anlatılmaktadır.

\subsection{Deprem Kayıtları}

Theophanes Kroniğinde değişik tarihlerde Bizans coğrafyasında yaşanan birçok deprem hakkında oldukça dikkat çekici bilgiler vermektedir. Nitekim onun verdiği bilgilere göre İskenderiye (Mısır) kentinde 319 yılında çok şiddetli bir deprem olmuş, birçok ev yıkılırken bir hayli insan da yaşamını kaybetmiştir (Mango vd. 1997: 29). Theophenes kroniğinde verilen bilgilere göre, 332 yılında Kıbrıs'1n Salamis ${ }^{3}$ şehrinde meydana gelen şiddetli depremde ise şehir yıkılmış, birçok insan hayatını yitirmiş (Mango vd. 1997: 48); 341 yılında Antakya'da meydana gelen şiddetli deprem 3 gün sürmüş (Mango vd. 1997: 60), 342 yılında meydana gelen şiddetli deprem sırasında Salamis şehri yıkılmış (Mango vd. 1997: 61), 343 yılında meydana gelen şiddetli deprem sırasında Niksar şehri, kilise ve piskoposun sarayı dışında yıkılmış (Mango vd. 1997: 62) aynı yılda (343) Rodos adası şiddetli deprem nedeniyle yıkılmıştır (Mango vd. 1997: 62). Theophenes, 344 yılında Draç (Arnavutluk) kentinin deprem nedeniyle

\footnotetext{
${ }^{3}$ KKTC, Gazimagusa şehri yakınlarında yer alan bir antik kent.
} 
tahrip olduğunu, Roma'nın üç gün boyunca sallandığını ve Campania'daki ${ }^{4}$ on iki şehrin yok olduğunu; 347 yılında Beyrut (Lübnan) kentinin büyük bir kısmının şiddetli bir deprem sırasında çökmesi sonucunda birçok paganın kiliseye Hıristiyan olmak için girdiğini kaydetmiştir (Mango vd. 1997: 65). 357 y1lında Theophenes İzmit’in gece 11:00 sularında meydana gelen şiddetli bir depremde yıkıldığı ve pek çok kişinin hayatını kaybettiği bilgisini vermiştir (Mango vd. 1997: 75).

Theophenes 367 yılında meydana gelen deprem ve ardından oluşan Tsunamiyi ise şöyle anlatmıştır: "Bütün dünyada gece boyunca büyük bir deprem oldu, böylece kıyıda bulunan İskenderiye demirli gemileri yüksek binaların, duvarların üzerinden aştı ve şehir içinde avlu ve evlerin arasında sürüklendi. Su geri çekildiğinde kuru arazide kaldılar. Deprem yüzünden şehirden kaçan insanlar, karadaki gemileri yağmalamaya gittiler. Ama geri dönen su hepsini yuttu. O sırada Adriyatik'te yelken açan denizcilerin gemileri deniz yatağında karaya oturdu. Ancak kısa bir süre sonra sular tekrar deniz yatağını doldurdu ve yolculuklarına devam ettiler” (Mango vd. 1997: 75).

Theophenes 407 y1lında yedi gün boyunca meydana gelen deprem nedeniyle Roma'da yerin inlediğini (Mango vd. 1997: 123), 437 y1lında İstanbul'da dört ay süren şiddetli depremler meydana geldiğini, Bizanslıların şehirden korkuyla kaçtıklarını ve piskoposla birlikte günlerini Tanrıya yalvararak geçirdiklerini kroniğinde anlatmıştır (Mango vd. 1997: 144). 442 yılında, Mayıs ayından on beş gün önce (17 Nisan 442) meydana gelen depremde dünyanın sarsıldığını ve inlediğini yine kroniğinde bildirmiştir (Mango vd. 1997: 150). Onun verdiği bilgiye göre 457 y1lında Antakya'da meydana gelen korkunç depremde nerdeyse tüm şehir yok olmuştur (Mango vd. 1997: 170).

Theophenes kroniğinde 25 Eylül 478 yılında İstanbul'da korkunç bir deprem olduğunu, çok sayıda kilise ve evin yıkıldığını, sayısız insanın gömüldüğünü, Forumdaki dünya heykeli ile Theodosios heykelinin düştüğünü, duvarlarda büyük çatlaklar oluştuğunu, depremin çok uzun sürdüğünü bu yüzden şehrin kokmaya başladığını anlatmıştır (Mango vd. 1997: 193). 502 yılında Niksar'da meydana gelen depremde şehir St. Gregori kilisesi dışında tamamen yıkılımıştır (Mango vd. 1997: 223). 506 y1lında meydana gelen deprem Theophenes kroniğinde Anastasios'un (430/431518) emri ile Büyük Konstantin adına yapılan bronz eserlerin ve kendi adına dikilen heykellerin deprem sırasında düşüp paramparça olduğunu anlatmıştır. 521 yılında Draç'ın (Arnavutluk) tanrının gazabına (deprem) uğradığını, imparatorun şehrin tamiratı için çok fazla para harcadığını Theophenes kroniğinden öğreniyoruz. (Mango vd. 1997:

\footnotetext{
${ }^{4}$ İtalya'nın güneyinde kısmi özerklik verilmiş bölge.
} 
256). Theophenes kroniğinde 524 y1lında Anazarbos'un ${ }^{5}$ korkunç depremden etkilendiğini ve tüm şehrin çöktüğünü (Mango vd. 1997: 262), 4 Ekim 525 y1lında Tanrı'nın öfkesinin (deprem) Antakya kentini ziyaret ettiğini anlatmıştır (Mango vd. 1997: 263).

Theophenes kroniğinde 26 Mayıs 526 tarihinde meydana gelen depremde Antakya piskoposu Euphrasios’un deprem sirasında yutulduğunu ve yok olduğunu, evlerin, kiliselerin çöktüğünü ve şehrin güzelliğinin yok olduğunu, hiçbir neslin Tanrının bu derece büyük bir afetine maruz kalmadığını anlatmıştır (Mango vd. 1997: 264). 29 Kasım 528 yılı Çarşamba günü Antakya'da meydana gelen depremin bir saat sürdüğünü, korkunç bir gürültü işitildiğini, tüm binaların ve duvarların devrildiğini, 526 yılında yaşanan depremde yıkılmayan eski binaların yıkıldığını Theophenes kroniğinden anlıyoruz (Mango vd. 1997: 270). Theophenes 535 y1lında Pompeiopolis ${ }^{6}$ şehrinde meydana gelen depremde yerin bölündüğünü ve insanlarla birlikte şehrin yarısının yutulduğunu, bağırmalarının duyulduğunu, imparatorun kazı yaparak onlara yardım ettiğini ve hayatta kalanlara hediye verdiğini kroniğinde anlatmıştır (Mango vd. 1997: 314). Theophenes kroniğinde 16 Ağustos 542 tarihinde İstanbul'da büyük bir deprem meydana geldiğini, kiliselerin, evlerin, Altın Kapı yakınındaki şehir duvarının bir kısmının çöktüğg̈nü, birçok insanın öldüğünü ve şehirde büyük korku yaşandığını (Mango vd. 1997: 322), 6 Eylül 543 yılında Pazar günü dünya çapında büyük bir deprem olduğunu (Mango vd. 1997: 324), 545 y1lında Bizans'ta yine büyük bir deprem olduğunu (Mango vd. 1997: 326), 548 yılı Şubat ayında bir dizi deprem meydana geldiğini (Mango vd. 1997: 329), 9 Temmuz 551 yılında Filistin, Arabistan, Mezopotamya, Suriye ve Finike'de şiddetli ve korkutucu bir deprem olduğunu, Sur ${ }^{7}$, Sayda $^{8}$, Beyrut, Trablus ${ }^{9}$ ve Biblos ${ }^{10}$ 'da çok sayıda insan öldüğünü, Batroun ${ }^{11}$ şehrinde, denize yakın duran Lithoprosopon ${ }^{12}$ dağının büyük bir kısmının kırılarak denize düştüğünü, denizin bir mil geriye çekildiğini ve birçok geminin kaybolduğunu, daha sonra denizin kendi yatağına geri döndüğünü anlatmıştır (Mango vd. 1997: 332). Theophenes kroniğinde devamla 15 Ağustos 554 pazar günü, geceleyin korkunç bir deprem olduğunu, özellikle Altın Kapı yakınlarında birçok ev, hamam, kilise ve şehir

\footnotetext{
${ }^{5}$ Adana'nın Kozan ilçesinin 28 km güneyinde bulunan antik kent.

${ }^{6}$ Yeri bilinmiyor

${ }^{7}$ Lübnan'ın Akdeniz kıyısında yer alan antik dönemdeki Tyre olan tarihi liman kenti

${ }^{8}$ Beyrut'un güneyinde Akdeniz sahilindeki eski ismi Sidon olan şehir

${ }^{9}$ Beyrut'un 85 km kuzeyinde yer alan antik dönemdeki ismi Tripolis olan şehir

${ }^{10}$ Beyrut'un kuzeyinde yer alan antik liman kenti

${ }^{11}$ Kuzey Lübnan'da yer alan antik dönemdeki ismi Botrys olan dünyanın en eski kıyı kentilerinden biri

${ }^{12}$ Bugün Râs ach-Chaq'a' adıyla bilinen, kuzey Lübnan'da eski adi bir burun
} 
surlarının bir kısmının zarar gördüğünü, birçok insanın öldüğünü, İzmit’te de bir çok evin çöktüğünü ve sarsıntıların 40 gün sürdüğünü ifade etmiştir (Mango vd. 1997: 335).

11 Temmuz 555 günü büyük bir deprem olduğunu (Mango vd. 1997: 336), 16 Nisan 557 Pazartesi günü hiçbir hasara yol açmayan korkutucu bir depremin olduğunu yine Theophenes kroniğinden öğreniyoruz (Mango vd. 1997: 338). 558 y1lında meydana gelen depremleri Theophenes kroniğinde şu şekilde kaydetmiştir: “19 Ekim 558 Cuma günü bir deprem oldu, cumartesi günü doğmak üzereydi.14 Aralık 558'de, İstanbul'un hem Constantinos (272-337) hem de Theodosios (347-395) tarafindan inşa edilen iki duvarına zarar veren çok korkutucu başka bir deprem oldu. Depremin korkunç tehdidinden zarar görmeyen bir yer yoktu. St Stratonikos ve St Kallinikos kiliseleri, her ikisi de Rhegion'da toprağa çöktü. Secundianai (Iucundianae) Sarayının önünde duran heykelin önündeki porfir sütunu çöktü ve yere 8 metre gömüldü. Çöken binalarda çok sayıda kayıp vardı. Bazı insanlar harabeye gömüldükten iki ya da üç gün sonra kurtarıldı. Aynı durumun diğer şehirlerde de olduğu bildirildi. Bu neslin yeryüzündeki hiçbir insanı böyle çok büyük ve korkunç bir depremi daha önce yaşamamıştır. Dünya on gün boyunca gündüz ve gece sallanmaya devam etti” (Mango vd. 1997: 339). Theophenes 10 Mayıs 583 tarihinde büyük bir deprem olduğunu, herkesin kiliselere sığındığını ve bu nedenle at arabası yarışlarının yapılmadığını kroniğinde bildirmiştir (Mango vd. 1997: 374).

Yine onun verdiği bilgiye göre 632 yılında Filistin'de bir deprem olmuştur. Ayrıca depremden sonra gökyüzünde güneyden kuzeye uzanan kılıç şeklinde bir işaret gözlenmiştir (Mango vd. 1997: 467). Theophanes, 658 y1lı haziran ayında Filistin ve Suriye şehirlerini yıkan büyük bir depremin olduğu bilgisini vermiştir (Mango vd. 1997: 484). 678 y1lında Theophanes'in Mezopotamya'da meydana gelen şiddetli bir depremin Urfa’daki kilisenin vaiz kürsüsünü ve kubbesini yıktığını söylemiştir (Mango vd. 1997: 497). 28 Şubat 713 yılında yine Suriye'de güçlü bir depremin meydana geldiğini kaydetmiştir (Mango vd. 1997: 533).

Theophanes, 718 yılında Suriye'de meydana gelen güçlü bir depremden sonra ise Halife Halife Ömer bin Abdülaziz'in ${ }^{13}$ şarabı yasakladığını ve Hristiyanları din değiştirmeye zorladığına dair bilgileri kroniğinde anlatmaktadır. Bu depremle ilgili bilgi verirken İslam inancına hiç uymayan ifadelerle Halife Ömer’in dinden dönenleri vergiden muaf tuttuğunu, dönmeyenleri ise öldürdüğünü ifade etmiştir. Ayrıca Hristiyanların bir Saracen' $\mathrm{e}^{14}$ karşı şahitliğinin kabul edilemez olduğuna dair yasa

\footnotetext{
13 8.ci Emevi Halifesi, Doğumu 682 ve Ölümü 720.

${ }^{14}$ Haçlıların Müslüman ve Türklere "Hristiyan olmayan" anlamında taktığı ad
} 
çıkardığını; Bizans İmparatoru V. Leo’yu ise din değiştirmeye ikna etmek amacıyla dogmatik bir mektup gönderdiğini kroniğinde kaydetmiştir (Mango vd. 1997: 550).

Theophanes, kroniğinde 26 Ekim 740, çarşamba günü saat 8:00'da İstanbul'da güçlü ve korkutucu bir deprem meydana geldiğini, birçok kilise ve manastırın devrildiğini ve çok sayıda insanın öldüğünü bildirmiştir. Attalos Kapıs1 ${ }^{15}$ üzerindeki Büyük Konstantin heykelinin kapının kendisi gibi düştüğünü, Xerolophos kolonu üzerindeki Arkadios anıtının ve Altın Kapı geçidi üzerindeki Büyük Thedosios heykelinin devrildiğini, Trakya, Nikomedeia (İzmit), Prainetos (Karamürsel) ve Nikaia’daki (İznik) şehir duvarlarının, kasaba ve köylerin de aynı şekilde yıkıldığını anlatmaktadır. Bazı yerlerde denizin kendi sınırlarından geriye çekildiğini, artçı şokların 12 ay boyunca devam ettiğini kaydetmiştir (Mango vd. 1997: 572).

742 yılında Saba ${ }^{16}$ çölünde karşı karşıya olan dağların bulunduğu alanda bir deprem meydana geldiğini ve bölgedeki köylerin yeraltına gömüldüğünü anlatmıştır (Mango vd. 1997: 577). 742 y1lında Hazar geçidinde de bir depremin olduğunu kaydetmiştir (Mango vd. 1997: 579). 18 Ocak 746 tarihinde, saat 4:00'da Filistin, Ürdün ve tüm Suriye'de güçlü bir deprem olduğu, on binlerce kişinin öldüğü ve özellikle kutsal şehrin etrafını çevreleyen çölde kilise ve manastırların yıkıldı̆̆ gözleminden bahsetmiştir (Mango vd. 1997: 585).

Theophanes kroniğinde 749 yılında Suriye'de meydana gelen bir deprem ile büyük ve dehşet verici bir çökme hakkındaki gözlemlerini, deprem sonrasında şehirlerin bazılarının tamamen, bazılarının ise kısmen yerle bir olduğunu anlatmıştır. Gözlem yaptığı yerlerde dağlardan ovalara kadar duvarlardan binalara kadar her şeyin 6 mil veya biraz daha fazla hareket ederek aşağıya doğru gömüldüklerini söylemiştir. Görgü şahitlerinin anlattıklarına da yer veren Theophanes Mezopotamya topraklarının tamamıyla 2 mil derinliğe kadar birbirinden ayrilarak koptuğunu, bu derinlikten çok beyaz ve kumlu yeni bir toprağın ortaya çıktığını anlatmışlardır (Mango vd. 1997: 589).

Theophanes, 9 Mart 756 tarihinde Filistin ve Suriye’de küçük olmayan bir deprem olduğunu söylemiştir (Mango vd. 1997: 594). 9 Şubat 790 tarihinde korkunç bir deprem olduğunu, insanların bazılarının evlerinde uyumaya cesaret edemediğini, zamanlarını meyveliklerde ve açık hava çadırlarında geçirdiklerini ifade etmiştir (Mango vd. 1997: 639). Nisan 796 yılında bir cumartesi gecesi Girit adasında korkunç bir depremin, 4 Mayıs 796 tarihinde ise İstanbul'da ürkütücü başka bir depremin olduğunu kroniğinde kaydetmiştir (Mango vd. 1997: 646).

\footnotetext{
${ }^{15}$ Thedosius hanedanlığı döneminde yapılan Altın Kapı

${ }^{16}$ Güney Arabistan’da bir çöl
} 


\subsection{Kuraklık ve Kıtlık Kayıtları}

Theophanes, yaşadığı dönemde Bizans’ta yaşanan kuraklık ve kıtlık olaylarına da kroniğginde yer vermiştir. 331 yılında, Doğu'da büyük bir kıtlık meydana geldi, bu nedenle köylülerin bir araya toplanarak gece-gündüz birbirlerine saldırdıkları ve hırsızlık yaptıklarını, kıtlık nedeniyle gıda fiyatlarının aşırı şekilde yükseldiğini (Mango vd. 1997: 47), 563 yılı kasım ayında kuraklık nedeniyle suların azaldığını, çeşmelerin etrafında birçok kavga meydana geldiğini (Mango vd. 1997: 349), 684 yılında Suriye’de kıtlık ile birlikte büyük bir veba olduğunu (Mango vd. 1997: 503), 686 y1lında ise Suriye'de kıtlık nedeniyle erkeklerin çoğunun Romanya’ya gittiğini kaydetmiştir (Mango vd. 1997: 507). Theophenes 717 yılında Arapların ciddi bir kıtlık içinde olduklarını, bu nedenle at, eşek ve deve gibi ölü hayvanları yediklerini (Mango vd. 1997: 546), 743 yılında yine Saba çölünde (Mango vd. 1997: 577) ve Bizans’ta şiddetli bir kuraklık yaşandığını aktarmıştır. 743 yılında Bizansta yaşanan kıtlığın şiddetle büyüdüğünü ifade eden kroniği şu şekilde devam etmektedir: "O kadar ki yaklaşı 2 galon ${ }^{17}$ arpa 12 nomismataya ${ }^{18}$ satıldı, 2 galon bakliyat 19 nomismataya ve darı veya acıbakla bile 8'e satıldı. 5 poundluk ${ }^{19}$ zeytinyağları 1 nomismaya ve bir xestes ${ }^{20}$ şarap bir nomismatanın yarısına satıldı. İnsanlar öldüğü için, Artavasdos ${ }^{21}$ şehirden ayrılmaları için halka izin vermek zorunda kaldı” (Mango vd. 1997: 580).

Bir başka kıtlık bilgisi de şu şekilde anlatılmaktadır: “763 yılının mart ayında yaşanan kötü bir kuraklık su kaynaklarını kurutmuştur” (Mango vd. 1997: 601). 766 yılında yaşanan kuraklık nedeniyle gökyüzünden hiç saf su düşmedi ve halk tümüyle şehri terk etmişti. Su depoları ve hamamlar boşaldı. Bizans devleti yaşanan bu kıtlığa kayıtsız kalmamış ve bir dizi önlem almak durumunda kalmıştır. Bizans'a su getirmek amacıyla eski suyollarını tamir etmek için yoğun gayret içinde olmuştur. Bu durum kronikte şu şekilde anlatılmaktadır: "İmparator yaşanan kıtlığı gördüğünde Heraklius zamanına kadar kullanılan Valentinus Su Kemeri’ni yeniden inşa etmeye başladı. Ancak Avarlar tarafından yerle bir edildi. O çeşitli yerlerden yetenekli işçileri topladı ve onları İstanbul'a götürdü. Asya ve Pontus'tan 1.000 ev ustası, Yunanistan'dan 200 sivac1, adalardan 500 kiremit döşeyici, Trakya'dan 5.000 işçi ve 200 çömlekçi. İşçilerin sorumluluğuna müfettişler ve bir soylu koydu. Böylece iş bittiğinde su şehre ulaşmıştı” (Mango vd. 1997: 608).

\footnotetext{
${ }^{17}$ Katı maddeler için ağırlık ölçüsü

${ }^{18}$ Bizans dönemi para birimi (tekili nomisma)

${ }^{19}$ Sıvı maddeler için ağırlık ölçüsü

${ }^{20}$ Katı ve sıvı maddeler için hacim birimi

${ }^{21}$ Haziran 741-Kasım 743 yılları arasında hüküm süren Bizans İmparatoru
} 


\subsection{Meteorolojik Kayıtlar}

Theophanes Kroniğinde Bizans’ta özellikle Urfa şehrinde yaşanan Meteorolojik olaylara da yer vermiştir. 524 yılında büyük ve ünlü bir şehir olan Urfa'da, ortasından geçen Firat nehri nedeniyle sel meydana geldiğini, selin bir deniz gibi evleri sakinleriyle birlikte sürüklediğini ve batırdığını (Mango vd. 1997: 262), 19 Temmuz 555 tarihinde korkunç bir gök gürültüsü, şimşek ve şiddetli bir güney-batı rüzgârının olduğunu, bu nedenle Rhesion kapısının içinde duran haçın düştüğünü (Mango vd. 1997: 336), 667 yılında kışın Urfa'da bir tufan (sel baskını) olduğunu ve pek çok can kaybı yaşandığını anlatmıştır (Mango vd. 1997: 490). 673 yılının mart ayında gökyüzünde bir gökkuşağı görüldüğünü ve bütün insanlığın bu olay nedeniyle ürperdiğini ve herkesin bu olayı dünyanın sonu olarak söylediğini dile getirmiştir (Mango vd. 1997: 493). 717 y1lında Trakya'da kışın çok şiddetli geçtiğini anlatan Theophanes Kroniğinde 100 gün boyunca dünyayı kristal bir karın kapladığını, çok sayıda düşmanın atları, develeri ve diğer hayvanlarının öldüğünü bildirmiştir (Mango vd. 1997: 546). Theophanes Kroniğinde 724 yılında meydana gelen sel nedeniyle Urfa şehrinin sular altında kaldığını ve birçok insanın öldüğünü (Mango vd. 1997: 558), 28 Ocak 740 yılında yine Urfa'nın sel nedeniyle sular altında kaldığını (Mango vd. 1997: 572) ifade etmiştir. Theophanes Kroniğinde 763 yılı Ekim ayı başlarındaki şiddetli kış gözlemini şu şekilde anlatmıştır: "Bu yılda ekim ayı başlarından itibaren sadece bizim memleketimizde değil, doğuda, kuzeyde ve batıda çok keskin bir soğuk vardı. Soğuktan dolayı, Karadeniz'in kuzey kıyısı, yüzlerce mil uzaklığa ve otuz kubit ${ }^{22}$ derinliğe kadar dondu. Benzer durum balkanlarda Tuna, Dinyester, Dinyeper gibi birçok nehirde gerçekleşti. Bütün bu buz kütlesi sürekli kar yağması nedeniyle yirmi beş kubit daha büyüdü, böylece deniz kara ile birleşti. Kırım, Bulgaristan ve diğer komşu ülkelerde insanlar ve hayvanlar bu buzların üzerinde yürüyebiliyorlardı” (Mango vd. 1997: 600).

\subsection{Güneş Tutulması ve Gökyüzü Gözlemleri}

Theophanes, Bizans döneminde birçok gökyüzü gözlemi ve güneş tutulması olaylarını da Kroniğinde anlatmıştır. O döneme dair verdiği bilgilere göre 534 yılında gökyüzünde bir alamet şeklinde güneş tutulması meydana geldiğini, bir y1l boyunca güneşin karanlık ve ışınsız ay gibi parladığını, açık bir şekilde parlamadığını anlatmıştır (Mango vd. 1997: 297). 5 Kasım 644 yılında cumartesi günü saat 9:00’da yine güneş tutulması olduğunu Theophenes kroniğinde kaydetmiştir (Mango vd. 1997: 477). Bir başka güneş tutulması olayının 4 Ekim 693 Pazar günü meydana geldiğini ve bazı parlak yıldızların gökyüzünde görüldüğünü (Mango vd. 1997: 513), 15 Ağustos 760

\footnotetext{
${ }^{22}$ Bizansta kullanılan uzunluk ölçüsü birimi
} 
Cumartesi günü Afrika'da güneş tutulması sonrası savaş olduğunu (Mango vd. 1997: 597), 9 Eylül 787 günü Pazar günü kutsal ayin sırasında güneş tutulması gerçekleştiğini (Mango vd. 1997: 636), 20 Şubat 798 tarihinde güneşin on yedi gün boyunca karanllğa gömüldüğü ve 1şınlarını yaymadığı için gemilerin kaybolarak sürüklendiğini (Mango vd. 1997: 649), 14 Mayıs 811 Cuma günü üç buçuk saat süren büyük bir güneş tutulması olduğunu (Mango vd. 1997: 679) kroniğinde yazmıştır. Theophanes'in kroniğinde bir başka güneş tutulması ise şu şekilde ifade edilmiştir: "Yıldız haritasına göre 4 Mayıs 813’te Boğa Burcu 12 derecede iken Güneș doğarken tutuldu. Bu olay paniğe sebep oldu" (Mango vd. 1997: 680).

Theophanes’in kroniğinde gökyüzünde gözlenen Kuyruklu yıldız ve nişanelerini de kroniğine şu şekilde kaydetmiştir: “632 yılında Filistin’de meydana gelen depremden sonra gökyüzünde güneyden kuzeye uzanan kılıç şeklindeki bir işaret görülmüştür. 30 gün boyunca gökyüzünde kalan bu işaret Bizanslılar tarafinda Arap Fethi'nin gelişinin önceden habercisi olarak yorumlanmıştır” (Mango vd. 1997: 467). 30 gün boyunca gözlenmesi ve kılıç şeklinde olması sebebiyle bu işaretin Kuyruklu yıldız olması ihtimali yüksektir. 743 yılında Suriye'de büyük bir kuyruklu yıldız görüldü (Mango vd. 1997: 583). 759 yılında doğuda on gün boyunca çok parlak bir kuyruklu yıldız, batıda yirmi bir gün boyunca başka bir kuyruklu yıldız ortaya çıktı (Mango vd. 1997: 597). 762 yılında doğuda bir kuyruklu yıldız ortaya çıktı (Mango vd. 1997: 599). Bir başka kuyruklu yıldız gözlemi de şu şekilde kaydedilmiştir: “1 Kasım 813'te görülen kuyruklu yıldızın iki küçük ay şeklinde parladığı gözlendi. Onlar birleşti ve farklı bir şekil alarak kafasız bir adamın resmi gibi bir kez daha ayrıldılar” (Mango vd. 1997: 683).

Bizans'ta gözlenen ve anlam verilemeyen işaretler değişik tarihlerde gözlenmiştir ve şu şekilde kaydedilmiştir: "354 y1lında Hamsin Yortusu ${ }^{23}$ gününde hayat veren Haç işareti gökyüzünde ortaya çıktı. Aydınlıktı ve Mesih'in çarmıha gerildiği Golgotha'dan ${ }^{24}$, tutulduğu Zeytin Dağı'na ${ }^{25}$ uzanıyordu. Görünen işaretin tamamı gökkuşağı gibi bir taçtı" (Mango vd. 1997: 69). Theophanes kroniğinde 465 y1lında 40 gün boyunca her akşam gökyüzünde trompet şeklinde bir bulutun ortaya çıktığını (Mango vd. 1997: 178), 557 yılı kasım ayında gökyüzünde kuzeyden batıya doğru mızrak şeklinde bir ateşin ortaya çıktığını bildirmiştir (Mango vd. 1997: 338). Theophenes kroniğinde devamla 667 yılında Kışın Urfa'da gökyüzünde bir işaret görüldüğünü (Mango vd. 1997: 490), 674 yılında bir cumartesi günü gökyüzünde bir işaret belirdiğini (Mango vd. 1997: 495), 734 y1lında gökyüzünde yanan bir sembol gibi parlayan bir işaret görüldüğünü (Mango vd. 1997:

\footnotetext{
${ }^{23}$ Hristiyanlıktaki başlıca bayramlardan biri

${ }^{24}$ Kudüs surlarının hemen dışında İsa'nın çarmıha gerildiğine inanılan tepe

${ }^{25}$ Kudüs'ün doğusunda yer alan Zeytin ağaçlarıyla dolu tepe
} 
569), 742 y1lı haziran ayında gökyüzünün kuzeyinde bir işaret görüldüğünü (Mango vd. 1997: 577), ve 742 y1lında kuzeyde bir işaret görüldüğünü, çeşitli yerlere tozlar düştüğünü kaydetmiştir (Mango vd. 1997: 579).

\section{Sonuçlar}

Bu çalışmada günümüz tarih araştırmacılarının çok da üzerinde durmadıkları toplam 33 adet yer bilimleri ve doğa gözlemleri kaydının incelenmesiyle, Bizans toplumunun deprem algısı ve doğa olaylarına dini bakış açıları değerlendirilmeye çalışılmış olup aşağıdaki sonuçlara ulaşılmıştır.

1. Theophanes Kroniğinde 14 adet olmak üzere en fazla deprem olayına yer vermiştir. Anadolu'nun bir deprem kuşağı üzerinde bulunması nedeniyle bu coğrafyada her dönem depremlerin meydana gelmiş olması doğaldır. En fazla deprem kaydına yer verilmesinin ana nedeni olarak depremlerin yıkım ve ölüm sonucu insanları daha fazla etkilemesi olduğu kanaatine varılmıştır.

2. Kronikte anlatılan gözlemlere göre Bizans imparatorluğunda halkın doğa olayları ve oluş sebepleri hakkında bilgi seviyesinin oldukça düşük olduğu görülmüştür. Basit olaylar dahi abartılı şekilde anlatılarak dünyanın sonuna ve kıyamet olayına atfedilmiştir.

3. Bizanslılar genel olarak depremleri işledikleri günahlardan dolayı Tanrının kendilerini cezalandırma aracı olarak düşünmüşlerdir. Depremler ve ardından görülen gökyüzü gözlemleri bölgelerinde yaşanacak savaşlar ve fetihlere yorumlanmıştır.

4. Deprem kayıtlarının gözlendiği yerler dikkate alındığında İstanbul ve çevresi ile Suriye-Filistin bölgesi olmak üzere iki farklı bölge öne çıkmıştır. Tüm Anadolu coğrafyasında depremlerin olduğu düşünüldüğünde Bizans bilim merkezlerinin bu iki bölge etrafında yoğunlaştığı ortaya çıkmaktadır.

5. Yine deprem kayıtlarında yer verilen (750, Suriye depremi) düşey atım miktarları bölgede oluşan depremlerin mekanizmaları hakkında yer bilimcilere önemli bir kaynak sunmaktadır.

6. Kuraklık/Kıtlık, şiddetli kış, sel/tufan gibi gözlemleri Bizans'ın o döneminin iklim bilgisinin ortaya konulmasında yardımcı veri olarak kullanılabilir.

\section{Teşekkür}

$\mathrm{Bu}$ çalışmanın ortaya çıkmasında ve kalitesinin artırılması konusunda eleştirileriyle destek veren hakemlere, dergi editörüne teşekkür ederiz. 


\section{Kaynakça}

BAHADIR, Gürhan (2011). “Anadolu’da Bizans-Sasani Etkileşimi (IV.-VII Yüzylllar)”, International Periodical For The Languages, Literature and History of Turkish or Turkic, 6/1: 685-703.

BAKIR, Mevlüde (2005). "Depremlerin Oluş Nedenlerine İlişkin Bizans Teorileri”, ITÜ̈ Sosyal Bilimler Dergisi, 2 (1): 3-9.

BERBERCAN, Mehmet Turgut (2013). “İtirafçı Theophanes’in Kitabındaki Batı Türkleri Üzerine Notlar”, Karatekin Edebiyat Fakültesi Dergisi (KAREFAD), 1(1): 219230.

The Chronicle of Theophanes Confessor Byzantine and Near Eastern History (AD 284- 813), Çev. Cyril Mango, Roger Scot ve Yardımcısı Geoffrey Greatrex, Clarendon Press, Oxford 1997.

The Chronicle of Theophanes: Anni Mundi 6095-6305 (AD 602-813), Çev. Turtledove, Harry, University of Pennsylvania Press, USA 1982.

KARATAY, Osman (2010). “Tuna Bulgar Devletinin İlk Asrı: Balkanlarda Tutunma ve Pekişme (681-803)” Türk Dünyası İncelemeleri Dergisi, X/2: 1-18.

KARATAY, Osman (2014). "Karadeniz Kuzeyindeki Bucak Yer Adının Kökenine Dair”, Karadeniz Araştırmaları, 43: 51-57.

KOÇAK, Talat (2015). “Bizans (Doğu Roma) İmparatorluğu'nda Türk Kökenli Bir Komutan: Bardanes Tourkos ve İsyanı”, History Studies International Journal of History, 7(2): 67-76. 
Çizelge 1. Theophanes Kroniğinde doğal olaylar ve yer bilimleri kayıtlarının kronolojik listesi.

\begin{tabular}{|c|c|c|c|c|}
\hline $\begin{array}{l}\text { Sira } \\
\text { No }\end{array}$ & Tarihi & Olay & Yeri & Gözlemler \\
\hline 1 & 319 & Deprem & İskenderiye & Çok şiddetli bir deprem olmuş, birçok ev yıkılmış, bir hayli insan da yaşamını kaybetmiştir. \\
\hline 2 & 331 & Kitlık & İstanbul & Köylüler bir araya toplanarak gece-gündüz birbirlerine saldırmışlar ve hırsızlık yapmışlardır. \\
\hline 3 & 332 & Deprem & Salamis & Şiddetli depremde Salamis şehri yıkılmış, birçok insan hayatını yitirmiştir. \\
\hline 4 & 341 & Deprem & Antakya & Şiddetli deprem 3 gün sürmüştür. \\
\hline 5 & 342 & Deprem & Salamis & Salamis şehri yıkılmıştır. \\
\hline 6 & 343 & Deprem & Niksar & Niksar şehri, kilise ve piskoposun sarayı dışında yıkılmıştır. \\
\hline 7 & 343 & Deprem & Rodos & Rodos adası şiddetli deprem nedeniyle yıkılmıştır. \\
\hline 8 & 344 & Deprem & Draç (Arnavutluk) & Kent deprem nedeniyle tahrip olmuştur. \\
\hline 9 & 347 & Deprem & Beyrut (Lübnan) & Kentin büyük bir kısmı şiddetli bir deprem sırasında çökmüştür. \\
\hline 10 & 354 & İşaret & İstanbul & Hamsin Yortusu gününde Haç işareti gökyüzünde ortaya çıkmıştır. \\
\hline 11 & 357 & Deprem & İzmit & $\begin{array}{l}\text { Gece 11:00 sularında meydana gelen şiddetli depremde şehir yıkılmış ve pek çok kişi } \\
\text { hayatını kaybetmiştir. }\end{array}$ \\
\hline 12 & 367 & Deprem & İstanbul & Depremin ardından Tsunami oluşmuştur. \\
\hline 13 & 407 & Deprem & İstanbul & Yedi gün boyunca yer inlemiştir. \\
\hline
\end{tabular}




\begin{tabular}{|c|c|c|c|c|}
\hline 14 & 437 & Deprem & İstanbul & Dört ay süren şiddetli depremler meydana gelmiştir. \\
\hline 15 & 17 Nisan 442 & Deprem & İstanbul & Dünya sarsılmış ve inlemiştir. \\
\hline 16 & 457 & Deprem & Antakya & Depremde nerdeyse tüm şehir yok olmuştur. \\
\hline 17 & 465 & İşaret & İstanbul & 40 gün boyunca her akşam gökyüzünde trompet şeklinde bir bulutun ortaya çıkmıştır. \\
\hline 18 & 25 Eylül 478 & Deprem & İstanbul & Çok sayıda kilise ve evin yıkılmış, sayısız insan gömülmüştür. \\
\hline 19 & 502 & Deprem & Niksar & Şehir St. Gregori kilisesi dışında tamamen yıkılmıştır. \\
\hline 20 & 506 & Deprem & İstanbul & Yapılan bronz eserler ve dikilen heykeller düşüp paramparça olmuştur. \\
\hline 21 & 521 & Deprem & Draç (Arnavutluk) & Şehir Tanrının gazabına (deprem) uğramıştır. \\
\hline 22 & 524 & Deprem & Anazarbos & Tüm şehir çökmüştür. \\
\hline 23 & 524 & Sel & Urfa & Sel bir deniz gibi evleri sakinleriyle birlikte sürüklemiş ve batırmıştır. \\
\hline 24 & 4 Ekim 525 & Deprem & Antakya & Tanrı'nın öfkesi kenti ziyaret etmiştir. \\
\hline 25 & 26 May1s 526 & Deprem & Antakya & Evler, kiliseler çökmüştür. \\
\hline 26 & 29 Kasım 528, Çarşamba & Deprem & Antakya & Deprem bir saat sürmüş, korkunç bir gürültü işitilmiş, tüm binalar ve duvarları devrilmiştir. \\
\hline 27 & 534 & Güneş tutulması & İstanbul & Gökyüzünde bir alamet şeklinde güneş tutulması meydana gelmiştir. \\
\hline 28 & 535 & Deprem & Pompeiopolis & $\begin{array}{l}\text { Yer bölünmüş ve insanlarla birlikte şehrin yarısı yutulmuştur. Yerin içinden bağırışımalar } \\
\text { duyulmuştur. }\end{array}$ \\
\hline
\end{tabular}




\begin{tabular}{|c|c|c|c|c|}
\hline 29 & 16 Ağustos 542 & Deprem & İstanbul & $\begin{array}{l}\text { Kiliseler, evler, Altın Kapı yakınındaki şehir duvarının bir kısmı çökmüş, birçok insan } \\
\text { ölmüştür. Şehirde büyük korku yaşanmıştır. }\end{array}$ \\
\hline 30 & 6 Eylül 543, Pazar & Deprem & İstanbul & Dünya çapında büyük bir deprem olmuştur. \\
\hline 31 & 545 & Deprem & İstanbul & Büyük bir deprem olmuştur. \\
\hline 32 & Şubat 548 & Deprem & İstanbul & Bir dizi deprem meydana gelmiştir. \\
\hline 33 & 9 Temmuz 551 & Deprem & Mezopotamya & Şiddetli ve korkutucu bir deprem olmuştur. \\
\hline 34 & 15 Ağustos 554, Pazar & Deprem & İstanbul & $\begin{array}{l}\text { Geceleyin meydana gelen deprem özellikle Altın Kapı yakınlarında birçok ev, hamam, kilise } \\
\text { ve şehir surlarının bir kısmına zarar vermiştir. }\end{array}$ \\
\hline 35 & 15 Ağustos 554, Pazar & Deprem & İzmit & Birçok ev çökmüş ve sarsıntılar 40 gün sürmüştür. \\
\hline 36 & 11 Temmuz 555 & Deprem & İstanbul & Büyük bir deprem olmuştur. \\
\hline 37 & 19 Temmuz 555 & Gök gürültüsü & İstanbul & Korkunç bir gök gürültüsü yaşanmıştır. \\
\hline 38 & 16 Nisan 557, Pazartesi & Deprem & İstanbul & Hiçbir hasara yol açmamıştır. \\
\hline 39 & Kasım 557 & İşaret & İstanbul & Gökyüzünde kuzeyden batıya doğru mızrak şeklinde bir ateş ortaya çıkmıştır. \\
\hline 40 & 19 Ekim 558, Cuma & Deprem & İstanbul & Cumartesi günü gün doğarken meydana gelmiştir. \\
\hline 41 & 14 Aralık 558'de & Deprem & İstanbul & Çok korkutucu bir deprem olmuştur. \\
\hline 42 & Kasim 563 & Kuraklik & İstanbul & Suların azalmış, çeşmelerin etrafında birçok kavga meydana gelmiştir. \\
\hline
\end{tabular}




\begin{tabular}{|c|c|c|c|c|}
\hline 43 & 10 May1s 583 & Deprem & İstanbul & Herkes kiliselere sığınmış ve bu nedenle at arabası yarışlarının yapılamamıştır. \\
\hline 44 & 632 & Deprem & Filistin & Kuyruklu Yıldız gözlenmiştir. \\
\hline 45 & 632 & Kuyruklu yıldız & Filistin & Güneyden kuzeye uzanan kılıç şeklinde bir işaret görülmüştür. \\
\hline 46 & 5 Kasım 644, Cumartesi & Güneş Tutulması & İstanbul & Saat 09.00 meydana gelmiştir. \\
\hline 47 & Haziran 658 & Deprem & Filistin, Suriye & Şehirler yıkılmıştır. \\
\hline 48 & 667 & İşaret & Urfa & Gökyüzünde bir işaret görülmüştür. \\
\hline 49 & 667 & Sel, Tufan & Urfa & Pek çok can kaybı yaşanmıştır. \\
\hline 50 & Mart 672 & Gökkuşağ1 & İstanbul & Bütün insanlık ürpermiş, herkes bu olayı dünyanın sonu olarak yorumlamıştır. \\
\hline 51 & 674 & İşaret & İstanbul & Cumartesi günü gökyüzünde bir işaret belirmiştir. \\
\hline 52 & 678 & Deprem & Mezopotamya & Urfa'daki kilisenin vaiz kürsüsü ve kubbesi yıkılmıştır. \\
\hline 53 & 684 & Kitlik & Suriye & Büyük bir veba salgını olmuştur. \\
\hline 54 & 686 & Kitlik & Suriye & Erkeklerin çoğu Romanya'ya gitmiştir. \\
\hline 55 & 4 Ekim 693, Pazar & Güneş Tutulması & İstanbul & Bazı parlak yıldızlar görülmüştür. \\
\hline 56 & 28 Şubat 713 & Deprem & Suriye & Güçlü bir deprem olmuştur. \\
\hline 57 & 717 & Şiddetli Kış & Trakya & Çok sayıda düşmanın atları, develeri ve diğer hayvanları ölmüştür. \\
\hline 58 & 717 & Kitlik & Arabistan (Suriye?) & At, eşek ve deve gibi ölü hayvanları yemişlerdir. \\
\hline
\end{tabular}




\begin{tabular}{|c|c|c|c|c|}
\hline 59 & 718 & Deprem & Suriye & Güçlü bir deprem olmuştur. \\
\hline 60 & 724 & Sel & Urfa & Şehir sular altında kalmış ve birçok insanın ölmüştür. \\
\hline 61 & 734 & İşaret & İstanbul & Gökyüzünde yanan bir sembol gibi parlayan bir işaret görülmüştür. \\
\hline 62 & 28 Ocak 740 & Sel & Urfa & Şehir sular altında kalmıştır. \\
\hline 63 & 26 Ekim 740, Çarşamba & Deprem & İstanbul & $\begin{array}{l}\text { Birçok kilise, manastır devrilmiş, çok sayıda insan ölmüştür. Bazı yerlerde deniz çekilmesi } \\
\text { gözlenmiştir. }\end{array}$ \\
\hline 64 & 742 & Deprem & Saba çölü & Bölgedeki köyler yeraltına gömülmüştür. \\
\hline 65 & 742 & Kitlık & Saba çölü & \\
\hline 66 & 742 & Kuraklik & Bizans & \\
\hline 67 & 742 & Deprem & Hazar geçidi & \\
\hline 68 & Haziran 742 & İşaret & Saba çölü & Gökyüzünün kuzeyinde bir işaret görülmüştür. \\
\hline 69 & 742 & İşaret & İstanbul & Kuzeyde bir işaret görülmüş, çeşitli yerlere tozlar düşmüştür. \\
\hline 70 & 743 & Kitlik & Bizans & Fiyatlar artmıştır. \\
\hline 71 & 743 & Kuyruklu yıldız & Suriye & \\
\hline 72 & 18 Ocak 746 & Deprem & $\begin{array}{l}\text { Filistin, Ürdün, } \\
\text { Suriye }\end{array}$ & Saat 04:00'da olmuş, on binlerce kişi ölmüş, çölde kilise ve manastırlar yıkılmıştır. \\
\hline
\end{tabular}




\begin{tabular}{|c|c|c|c|c|}
\hline 73 & 749 & Deprem & Suriye & $\begin{array}{l}\text { Büyük ve dehşet verici çökme olmuş, şehirlerin bazıları tamamen, bazıları kısmen yıkılmış, } \\
\text { bazı yerlerde } 6 \text { mil düşey atım olmuş, } 2 \text { mil genişlikte fay kırığı oluşmuştur. }\end{array}$ \\
\hline 74 & 9 Mart 756 & Deprem & Filistin, Suriye & Küçük olmayan bir deprem oluşmuştur. \\
\hline 75 & 759 & Kuyruklu yıldız & İstanbul & Doğuda on gün boyunca çok parlak bir kuyruklu yıldız ortaya çıkmıştır. \\
\hline 76 & 759 & Kuyruklu yıldız & İstanbul & Batıda yirmi bir gün boyunca başka bir kuyruklu yıldız ortaya çıkmıştır. \\
\hline 77 & $\begin{array}{l}15 \text { Ağustos 760, } \\
\text { Cumartesi }\end{array}$ & Güneş tutulması & Afrika & Güneş tutulması sonrası savaş olmuştur. \\
\hline 78 & 762 & Kuyruklu yıldız & İstanbul & Doğuda bir kuyruklu yıldız ortaya çıkmıştır. \\
\hline 79 & Mart 763 & Kuraklık & İstanbul & Su kaynakları kurumuştur. \\
\hline 80 & Ekim 763 & Şiddetli kış & İstanbul & Soğuktan dolayı, Karadeniz'in kuzey kıyısı donmuştur. \\
\hline 81 & Mart 764 & Y1ldız kayması & İstanbul & Çağın sonu olarak yorumlanmıştır. \\
\hline 82 & 766 & Kuraklık & İstanbul & Halk şehri terk etmiştir. \\
\hline 83 & 9 Eylül 787, Pazar & Güneş tutulması & İstanbul & Kutsal ayin sırasında güneş tutulması gerçekleşmiştir. \\
\hline 84 & 9 Şubat 790 & Deprem & İstanbul & $\begin{array}{l}\text { İnsanların bazıları evlerinde uyuyamamış, meyveliklerde ve açık hava çadırlarında } \\
\text { yaşamışlardır. }\end{array}$ \\
\hline 85 & Nisan 796 & Deprem & Girit & Korkunç bir deprem olmuştur. \\
\hline 86 & 4 Mayıs 796 & Deprem & İstanbul & Ürkütücü bir deprem olmuştur. \\
\hline
\end{tabular}




\begin{tabular}{|c|c|c|c|c|}
\hline 87 & 20 Şubat 798 & Güneş tutulması & İstanbul & $\begin{array}{l}\text { Güneş on yedi gün boyunca karanlığa gömülmüş ve ışınlarını yaymadığı için gemiler } \\
\text { kaybolarak sürüklenmiştir. }\end{array}$ \\
\hline 88 & 14 Mayıs 811, Cuma & Güneş tutulması & İstanbul & Üç buçuk saat süren büyük bir güneş tutulması olmuştur. \\
\hline 89 & 4 Mayıs 813 & Güneş Tutulması & İstanbul & Paniğe sebep olmuştur. \\
\hline 90 & 1 Kasim 813 & Kuyruklu yıldız & İstanbul & İki küçük ay şeklinde parlamıştır. \\
\hline
\end{tabular}


Nafiz MADEN, Yasemin BEKER ve Bayram NAZIR, “Theophanes Kroniğinde Doğa Olayları ve Yer Bilimleri Gözlemleri”, Mavi Atlas, 6(2)/2018: 118-137.

Çizelge 2. Theophanes Kroniğinde yer alan gözlem ve kayıtlara ait istatistiki bilgiler.

\begin{tabular}{|l|c|}
\hline Olay & Sayısı \\
\hline Deprem & 49 \\
\hline Kuraklık/Kıtlık & 10 \\
\hline Güneş Tutulması & 8 \\
\hline İşaret & 8 \\
\hline Meteorolojik Kayıtlar (Şiddetli Kış, Sel, Tufan, Gökkuşağı) & 8 \\
\hline Kuyruklu yıldız & 6 \\
\hline Yıldız kayması & 1 \\
\hline & $\mathbf{9 0}$ \\
\hline
\end{tabular}

